\title{
Fiber-reinforced concrete for the flat bottom of silos
}

\author{
Rodrigo A. Constantino ${ }^{1}$, José P. Lopes Neto $^{1}$, Marcilene V. da Nóbrega ${ }^{2}$, José W. B. do Nascimento ${ }^{1}$ \& \\ Jefferson H. G. da Silva ${ }^{3}$
}

${ }^{1}$ Universidade Federal de Campina Grande/Centro de Tecnologia e Recursos Naturais/Unidade Acadêmica de Engenharia Agrícola, Campina Grande, PB, Brasil. E-mail: rodrigoconstantino_ecr7@hotmail.com (Corresponding author) - ORCID: 0000-0002-4472-1067; lopesneto@gmail.com - ORCID: 0000-0003-4960-5679; wallacebosa@hotmail.com - ORCID: 0000-0002-8376-0173

${ }^{2}$ Universidade Federal Rural do Semi-Árido/Departamento de Engenharias, Angicos, RN, Brasil. E-mail: marcilenenobrega@ufersa.edu.br - ORCID 0000-0003-2509-3672

${ }^{3}$ Universidade Federal de Campina Grande/Centro de Tecnologia e Recursos Naturais/Unidade Acadêmica de Engenharia Civil, Campina Grande, PB, Brasil. E-mail: jefferson389@hotmail.com - ORCID: 0000-0003-4955-8307

\begin{abstract}
The use of synthetic fibers as reinforcement for concrete replacing the steel reinforcement has been diffused worldwide in several applications, gaining prominence in the application for industrial floors, tunnel linings, road pavements, etc., i.e., continuous structures in contact with soil that require performance in the elastic medium. The present study investigated the applicability of concrete reinforced with synthetic fibers in the bottom slab of silos supported directly on the ground, being composed of an experimental study and a case study. The experimental study consisted of the analysis of the mechanical behavior of this concrete by testing three concentrations of synthetic fibers $\left(3.0,4.5\right.$ and $\left.6.0 \mathrm{~kg} \mathrm{~m}^{-3}\right)$ in a conventional simple concrete matrix. The case study consisted of the design of this part in conventional reinforced concrete and concrete reinforced with synthetic fibers with the objective of performing an economic comparison between the two projects. The experimental results showed that the fiber concentration that contributed to a better mechanical performance of the concrete matrix was $3.0 \mathrm{~kg} \mathrm{~m}^{-3}$. The case study showed that the most economical design was the one made with fiber-reinforced concrete.
\end{abstract}

Key words: mechanical behavior, design, alternative materials

\section{Concreto reforçado com fibras para o fundo plano de silos}

RESUMO: O emprego de fibras sintéticas como reforço para concretos em substituição das armaduras de aço vem sendo difundido mundialmente em diversas aplicações, ganhando destaque na aplicação para pisos industriais, revestimentos de túneis, pavimentos rodoviários, etc., isto é, estruturas contínuas em contato com o solo que requerem desempenho no meio elástico. O presente trabalho investiga a aplicabilidade do concreto reforçado com fibras sintéticas na laje de fundo de silos apoiados diretamente sobre o solo, sendo o mesmo composto por um estudo experimental e um estudo de caso. $\mathrm{O}$ estudo experimental resume-se na análise do comportamento mecânico desse concreto, testando-se três concentrações de fibras sintéticas (3.0, 4.5 e $6.0 \mathrm{~kg} \mathrm{~m}^{-3}$ ) numa matriz de concreto simples convencional. O estudo de caso consiste no dimensionamento dessa peça em concreto armado convencional e concreto reforçado com fibras sintéticas, com o objetivo de realizar um comparativo econômico entre os dois projetos. Os resultados experimentais mostraram que a concentração de fibras que contribuiu para melhor desempenho mecânico da matriz de concreto foi o de 3.0 $\mathrm{kg} \mathrm{m}^{-3}$. O estudo de caso mostrou que o projeto mais econômico foi o dimensionado com concreto reforçado com fibras.

Palavras-chave: comportamento mecânico, dimensionamento, materiais alternativos 


\section{INTRODUCTION}

Flat bottom silos with concrete base are structures that respond positively with regard to practicality of construction, ease in the handling of products stored, storage capacity, stability, watertightness and resistance.

Studies have been conducted with reference to the determination of pressures acting on flat bottom silos (Diniz \& Nascimento, 2006; Balevičius et al., 2011; Gallego et al., 2011; Rotter \& Sadowski, 2012; Nascimento et al., 2013; Lopes Neto et al., 2014; Wen et al., 2015; Horabik et al., 2016; Wang et al., 2016; Pieraccini et al., 2017; Frank et al., 2018). However, there is a need for studies on the use of new materials for the flat bottom of these silos, which are elements subject to dynamic, often non-uniform loads.

The addition of fiber to concrete changes some of its mechanical properties, such as the highest composite tensile strength, flexural strength, impact resistance and tenacity (Neves et al., 2013; Salvador \& Figueiredo, 2013; Pyo et al., 2015; Yoo et al., 2015; Mostafazadeh \& Abolmaali, 2016; Yaghoobi \& Chorzepa, 2017; Ghahremannejad et al., 2018; Leone et al., 2018; Monteiro et al., 2018; Ehrenbring et al., 2018) and, consequently, resistance to cracking.

The fibers that provide mechanical strength for the concrete are called macrofibers, among them steel and synthetic fibers. There is also the micro-fiber cloth, and its use does not include the increase of mechanical resistance of concrete in the hardened state; it improves some properties in the plastic state, such as shrinkage and exudation.

In this context, reinforced concrete has been presented as an alternative that seeks to improve the performance of limited conventional reinforcement structures in steel bars. Thus, the present study had as objective to conduct a case study of the effect of the addition of synthetic fibers in concrete slabs for the bottom of vertical silos and compare its performance and economic viability with conventional concrete.

\section{Material ANd Methods}

The experimental procedure was carried out in the Laboratory of Structures at the Universidade Federal de Campina Grande (UFCG), Campina Grande, PB, Brazil, and consisted of: concrete mix; determination of consistency; production of specimens; determination of compression strength in cylindrical specimens and determination of tensile strength in bending on prismatic specimens.

CP-II-Z 32 Portland cement was used in the study. Aggregate average river washed sand was used as fine aggregate. Pea gravel $19 \mathrm{~mm}$ was used as coarse aggregate. As an alternative to improve the workability, the additive plasticizer Stagnoflex was added to the mix.
Table 1. Properties of macrofibers

\begin{tabular}{|ll|}
\hline \multicolumn{1}{|c|}{ Technical characteristics } \\
\hline Composition & Polypropylene \\
\hline Shape & Twisted monofilament \\
\hline Length & $54 \mathrm{~mm}$ \\
\hline Modulus of elasticity & $7 \mathrm{GPa}$ \\
\hline Tensile strength & $550-650 \mathrm{MPa}$ \\
\hline Fibers per kg in bundles & 110.000 \\
\hline Density & $0.91 \mathrm{~g} \mathrm{~cm}^{-3}$ \\
\hline Resistance to alkalis & Total \\
\hline Electrical conductivity & Void \\
\hline Absorption & Void \\
\hline Ignition point & $>400^{\circ} \mathrm{C}$ \\
Anchoring & Physical/chemical \\
Color of the fibers & Dark grey \\
\hline Recommended doses & 3 to $8 \mathrm{~kg} \mathrm{~m}^{-3}$ \\
\hline
\end{tabular}

The properties of the synthetic fibers used in the concrete matrix are listed in Table 1.

Table 2 shows which tests, fiber concentrations, quantities and dimensions of specimens that were used in the analysis of concrete reinforced with synthetic fiber and analysis of simple conventional concrete. The production of concrete was based on the method described by the standard JSCE-SF1 (JSCE, 1984).

To carry out this plan of testing, the concrete mix whose composition is specified in Table 3 was used.

For determining the consistency of concrete reinforced with synthetic macrofiber and simple concrete, slump test was conducted according to the procedure described by the standard NBR NM 67 (ABNT, 1998).

Compression strengths of plain concrete and concrete reinforced with synthetic macrofiber were obtained by following the test method proposed by the NBR 5739 (ABNT, 2007). The axial compressive strength is calculated by Eq. 1 .

$$
\mathrm{f}_{\mathrm{c}}=\frac{4 \mathrm{P}}{\pi \mathrm{D}^{2}}
$$

where:

$\mathrm{f}_{\mathrm{c}}$ - compressive strength, in $\mathrm{MPa}$;

$\mathrm{P}$ - maximum load applied, in $\mathrm{N}$; and,

$\mathrm{D}$ - specimen diameter, in $\mathrm{mm}$.

To characterize the tensile strength in bending, the procedures were followed according to the standard NBR 12142

Table 3. Composition of the concrete mix of material

\begin{tabular}{|lr|}
\hline Material & $\begin{array}{c}\text { Dose } \\
\left(\mathrm{kg} \mathrm{m}^{-3}\right)\end{array}$ \\
\hline Cement CP-II-Z 32 & 330.00 \\
\hline Fine aggregate & 825.00 \\
Coarse aggregate & 1023.00 \\
\hline Water & 198.00 \\
\hline Additive plasticizer & 1.32 \\
\hline W/C ratio & 0.65 \\
\hline
\end{tabular}

Table 2. Testing, fiber concentrations, quantities and dimensions of specimens

\begin{tabular}{|c|c|c|c|c|c|c|c|}
\hline \multirow{3}{*}{$\begin{array}{l}\text { Standards/ } \\
\text { Testing }\end{array}$} & \multirow{3}{*}{\multicolumn{4}{|c|}{$\begin{array}{l}\text { Fiber concentration } \\
\qquad\left(\mathrm{kg} \mathrm{m}^{-3}\right)\end{array}$}} & \multicolumn{3}{|c|}{ Specimens } \\
\hline & & & & & \multicolumn{2}{|c|}{ Quantity } & \multirow{2}{*}{$\begin{array}{l}\text { Dimensions } \\
\text { (mm) }\end{array}$} \\
\hline & & & & & By concentration & Total & \\
\hline NBR NM 67 (ABNT, 1998) & 0 & 3.0 & 4.5 & 6.0 & 5 & 20 & - \\
\hline NBR 5739 (ABNT, 2007) & 0 & 3.0 & 4.5 & 6.0 & 5 & 20 & $150 / 300$ \\
\hline NBR 12142 (ABNT, 2010) & 0 & 3.0 & 4.5 & 6.0 & 5 & 20 & $150 / 150 / 750$ \\
\hline
\end{tabular}


(ABNT, 2010). The tensile strength in bending is calculated according to Eq. 2.

$$
\mathrm{f}_{\mathrm{ctm}}=\frac{\mathrm{Pl}}{\mathrm{bd}^{2}}
$$

where:

$\mathrm{f}_{\mathrm{ctm}}$ - tensile strength in bending, in $\mathrm{MPa}$;

$\mathrm{P}$ - maximum load applied, in $\mathrm{N}$;

$\mathrm{L}$ - distance between blades, in $\mathrm{mm}$;

b - average width of the specimen in section, in $\mathrm{mm}$; and,

$\mathrm{d}$ - average height of the specimen at rupture, in $\mathrm{mm}$.

The experimental data were subjected to analysis of variance using a completely randomized design with four treatments consisting of the following fiber concentrations: $0,3.0,4.0$ and $6.0 \mathrm{~kg} \mathrm{~m}^{-3}$ and five repetitions, with means compared by Tukey test, at $\mathrm{p} \leq 0.05$.

The base of the silo was designed using the following experimental data of working pressures obtained by Fank et al. (2018): $\mathrm{P}_{\mathrm{V} \max }=170.73 \mathrm{kPa} ; \mathrm{P}_{\mathrm{H} \max }=79.26 \mathrm{kPa} ; \mathrm{F}_{\text {Amount }}$ $\max =39.80 \mathrm{t}$. The objective of the study was theoretical and experimental determination of the pressures in a vertical flat metal silo for storing corn.

In this step, the experimental data of the pressures were entered in the Eberick software for sizing the silo's base in reinforced concrete. This step was performed following the recommendations of the NBR 6118 (ABNT, 2014). The following theoretical data of concrete slab of the silo were used:

a) $\mathrm{f}_{\mathrm{ck}}=30.0 \mathrm{MPa}$; b) $\mathrm{E}=26.0 \mathrm{GPa}$; ) Specific weight $=$ $2500.0 \mathrm{~kg} \mathrm{~m}^{-3}$; d) Concrete covering $=3.0 \mathrm{~cm}$.

The following characteristics were adopted for the soil: sandy type soil; permissible pressure $0.4 \mathrm{MPa}$; cohesion of 0.05 $\mathrm{MPa}$; specific weight of $1600 \mathrm{~kg} \mathrm{~m}^{-3}$ and friction angle $30^{\circ}$.

The determination of fiber dose for the bottom element of the silo was also carried out from solicitation data experimental recorded following the recommendations for concrete slabs reinforced with synthetic fibers supported directly on the soil of the regulatory guide ACI 360R-10 (ACI, 2010), as follows:

With the active loading on the structure, the largest solicitation $\left(\mathrm{M}_{\max }\right.$, in $\left.\mathrm{N} \mathrm{mm}\right)$ was used to calculate the value of the coefficient of tenacity $\left(\mathrm{R}_{\mathrm{e}, 3}\right.$, in \%), given by Eq. 3, extracted from the regulatory guide ACI 360R-10 (ACI, 2010).

$$
\mathrm{M}_{\text {max }}=\left\{1+\left(\frac{\mathrm{R}_{\mathrm{e}, 3}}{100}\right)\left[\frac{\mathrm{f}_{\mathrm{ct}, \mathrm{f}} \mathrm{b} \mathrm{h}^{2}}{6}\right]\right\}
$$

where:

b - unit width, $(1 \mathrm{~mm})$;

$\mathrm{h}$ - slab thickness, in $\mathrm{mm}$.

Where $\mathrm{f}_{\mathrm{ct}, \mathrm{f}}$, in $\mathrm{MPa}$, is the tensile strength in bending of concrete without fiber calculated by Eq. 4 .

$$
\mathrm{f}_{\mathrm{ct}, \mathrm{f}}=0.429 \sqrt[3]{\left(\mathrm{f}_{\mathrm{ck}}\right)^{2}}
$$

where:

$\mathrm{f}_{\mathrm{ck}} \quad$ - feature compression know, in $\mathrm{MPa}$.

Therefore, in the maximum moment equation, Eq. 3, the value of $R_{e, 3}$ was extracted and the ideal dose of fiber could be determined.

For the cost analysis, the values cost and consumption were taken from the cost composition tables PINI (2015) and SINAPI (2017).

\section{Results AND Discussion}

The fineness modulus found for the material was of 2.45 and density was $1.32 \mathrm{~g} \mathrm{~cm}^{-3}$. According to the technical specifications, it can be classified as a medium sand. It was noted that the particle size of coarse aggregate was very homogeneous, remaining within the range from 9.5 to 19.1 $\mathrm{mm}$. According to its granulometry, it was possible to classify it as a number 1 pea gravel, where the maximum diameter is $19 \mathrm{~mm}$ and density is $1.79 \mathrm{~g} \mathrm{~cm}^{-3}$.

The results of the tests of consistency, axial compression in cylindrical specimens and flexural strength on prismatic specimens are presented in Table 4, which shows that the consistency index and/or slump of the concrete sample decreases with increasing fiber concentration in the concrete matrix.

However, although the addition of $3.0 \mathrm{~kg} \mathrm{~m}^{-3}$ of fiber in the mixture decreases this index by $8.03 \%$, the results showed no significant difference for the reference mix. Different situation is presented with the additions of 4.5 and $6.0 \mathrm{~kg} \mathrm{~m}^{-3}$, which led to reductions of 30.69 and $38.72 \%$ in the consistency index, respectively, compared to the reference matrix.

The decrease in the value of the consistency index represents an increase in the consistency of the mixture and indicates lower workability; Therefore, it is an important aspect to be considered by designers and applicators, since the workability directly influences the capacity of the concrete to be pumpable or not and the final finish of the surface.

It has also been observed in reinforced concrete that

\begin{tabular}{|c|c|c|c|c|}
\hline $\begin{array}{l}\text { Fiber concentration } \\
\qquad\left(\mathrm{kg} \mathrm{m}^{-3}\right)\end{array}$ & $\begin{array}{l}\text { Quantity } \\
\text { of samples }\end{array}$ & $\begin{array}{l}\text { Slump } \\
\text { (cm) }\end{array}$ & $\begin{array}{c}\text { Standard } \\
\text { deviation }(\mathrm{cm})\end{array}$ & $\begin{array}{l}\text { CV } \\
(\%)\end{array}$ \\
\hline \multicolumn{5}{|c|}{ Consistency test (slump test) } \\
\hline 0 & 3 & $10.33 \mathrm{a}$ & 0.47 & \multirow{4}{*}{6.00} \\
\hline 3.0 & 3 & $9.50 \mathrm{a}$ & 0.41 & \\
\hline 4.5 & 3 & $7.16 \mathrm{~b}$ & 0.24 & \\
\hline 6.0 & 3 & $6.33 b$ & 0.47 & \\
\hline & \multicolumn{3}{|c|}{$\begin{array}{c}f_{c \text { medium }}-28 \text { days } \\
(\mathrm{MPa})\end{array}$} & \\
\hline \multicolumn{5}{|c|}{ Axial compression test on cylindrical specimens } \\
\hline 0 & 4 & $5.45 \mathrm{c}$ & 0.12 & \multirow{4}{*}{6.39} \\
\hline 3.0 & 4 & $14.86 \mathrm{a}$ & 0.73 & \\
\hline 4.5 & 4 & $12.94 \mathrm{~b}$ & 0.65 & \\
\hline 6.0 & 4 & $2.69 \mathrm{~d}$ & 0.14 & \\
\hline \multicolumn{5}{|c|}{ Tensile test in bending on prismatic specimens } \\
\hline 0 & 4 & $5.78 b$ & 0.00 & \multirow{4}{*}{10.55} \\
\hline 3.0 & 4 & $8.30 \mathrm{a}$ & 1.11 & \\
\hline 4.5 & 4 & $8.15 \mathrm{a}$ & 0.42 & \\
\hline 6.0 & 4 & $5.33 \mathrm{~b}$ & 0.00 & \\
\hline
\end{tabular}
the consistency index decreases significantly from samples

Table 4. Consistency and strength of fiber-reinforced concrete

Means followed by the same letter do not differ statistically by Tukey test at $\mathrm{p} \leq 0.05$ 
without fibers to samples with fibers (Salvador \& Figueiredo, 2013; Monteiro et al., 2018), which reinforces the result of this research. The addition of fiber alters the consistency of the concrete and its workability mainly because when fiber is added to the concrete, there is also the addition of a large surface area that requires greater water absorption, producing an increase of cohesion and loss of mobility in the composite. Therefore, the longer the fiber, the greater the impact on the workability of concrete. This change depends on a number of factors, including the material that makes up the fiber, its geometry and fraction of dose, for example.

The results of the test of axial resistance to compression (Table 2) indicated that the addition of fiber in the mixture influences the compressive strength. The highest value was obtained with the addition of $3.0 \mathrm{~kg} \mathrm{~m}^{-3}$ of fibers, representing a percentage increase of $172.66 \%$ in relation to the resistance of the concrete. The addition of $4.5 \mathrm{~kg} \mathrm{~m}^{-3}$ of fibers led to an increase of $137.43 \%$ in relation to the same concrete resistance. However, the results of the addition of $6.0 \mathrm{~kg} \mathrm{~m}^{-3}$ of fiber showed that this concentration does not increase the resistance of the concrete when compared to the reference concrete, but decreases it by $50.64 \%$; in addition, it reduces the resistance when compared with the resistance promoted by the addition of 3.0 and $4.5 \mathrm{~kg} \mathrm{~m}^{-3}$, indicating that these concentrations are not interesting, confronting the recommendation by the manufacturer with respect to the maximum dose, which is $8.0 \mathrm{~kg} \mathrm{~m}^{-3}$. A hypothesis of what might have occurred to obtain such low resistance values is that the ideal dose is also a function of the strength of the concrete, since large amounts of fiber in the mixture can cause difficulty in total bonding of the cementitious paste with the aggregates, making the concrete class of low resistance more fragile.

When evaluating the influence of the addition of polymeric fibers on the mechanical properties of concrete by means of specimens made with conventional concrete, concrete with addition of polypropylene fibers and concrete with addition of polyethylene fibers of high modulus, Amaral Júnior et al. (2017) observed an increase of $3.6 \%$ in the compressive strength of the concrete with addition of polypropylene fibers compared to conventional concrete.

The results of the test of tensile strength in bending, by average analysis, indicated that the addition of fiber in the mixture influences tensile strength. Just as in the test for resistance to axial compression, the highest value found for tensile strength was obtained with the addition of $3.0 \mathrm{~kg} \mathrm{~m}^{-3}$ of fiber, which led to a $43.60 \%$ increase compared to the reference concrete resistance.

The results for the addition of $4.5 \mathrm{~kg} \mathrm{~m}^{-3}$, despite being lower, showed no significant difference from the results obtained with $3.0 \mathrm{~kg} \mathrm{~m}^{-3}$, showing a percentage increase of $41.0 \%$ compared to the strength of the reference concrete. The addition of $6.0 \mathrm{~kg} \mathrm{~m}^{-3}$ of fiber, as in the axial compression test, promoted no gain of tensile strength in the concrete when the values are compared with the values obtained from the reference concrete, confirming that applications of this dose are not interesting for the concrete with the strength class studied.

Increased tensile strength for the concretes with addition of polymeric fiber in relation to concrete without the addition of fiber is consistent with the result found by Amaral Júnior et al. (2017), an increase of $9.3 \%$ for the tensile strength in bending in specimens dosed with $9.0 \mathrm{~kg} \mathrm{~m}^{-3}$ for a simple concrete fiber with characteristic resistance of $25 \mathrm{MPa}$.

The resistance provided by the fiber is directly related to its adherence with the concrete matrix (Salvador \& Figueiredo, 2013). For higher strength of the concrete, the performance of the fiber can be extended. With the increased resistance of the concrete, the higher its densification, leading greater adherence of the matrix, leading to a greater resistance to tearing and mobilizing more fiber tensile strength during the process of opening of the fissure, i.e., in matrices with less resistance, the mechanism controlling the opening of fissure tends to be the tearing of fiber. Conversely, in matrices of higher resistance, fiber breakage predominates.

In this study, it was considered that the maximum vertical pressure $\left(\mathrm{P}_{\mathrm{V} \text { max }}\right)$ acts directly on the bottom slab of the silo, so the maximum horizontal pressure $\left(\mathrm{P}_{\mathrm{H} \max }\right)$ and the maximum force recorded in amounts $\left(\mathrm{F}_{\text {Amount max }}\right)$ would act directly on the rigidizer ring.

Table 5 presents the section data, sizing loads, active efforts, calculated steel reinforcements, total steel weight, total concrete volume, and total form area of silo bottom slab.

According to Figure 1 the values of the fiber concentration for the coefficient of tenacity $\left(\mathrm{R}_{\mathrm{e}, 3}\right)$ is equal to $2.5 \mathrm{~kg} \mathrm{~m}^{-3}$.

Next, the results of the economic comparison for the silo bottom slab element are presented and discussed based on the cost and consumption values taken from the cost composition tables PINI (2015) and SINAPI (2017). The cost for executing this element in reinforced concrete is compared to the cost for executing it in concrete reinforced with synthetic fibers.

Table 5. Silo bottom slab data

\begin{tabular}{|c|c|c|c|c|c|c|}
\hline \multicolumn{3}{|c|}{ Section (cm) } & \multicolumn{4}{|c|}{ Loads (kPa) } \\
\hline Slab h & Elevation & $\begin{array}{l}\text { Slab } \\
\text { level }\end{array}$ & $\begin{array}{l}\text { Own } \\
\text { weight }\end{array}$ & $\begin{array}{c}\text { Accidental } \\
\text { coating }\end{array}$ & $\begin{array}{l}\text { Other } \\
\text { walls }\end{array}$ & Total \\
\hline L1 & 0 & 70.0 & 4.75 & $\begin{array}{c}170.73 \\
0\end{array}$ & $\begin{array}{l}0 \\
0\end{array}$ & 175.48 \\
\hline \multirow[t]{2}{*}{ Efforts } & Mdx & & Mdy & Asx & Asy & \multirow{2}{*}{$\begin{array}{l}\text { Arrow } \\
(\mathrm{cm})\end{array}$} \\
\hline & \multicolumn{3}{|c|}{$\left(\mathrm{KN} \mathrm{m} \mathrm{m}^{-1}\right)$} & \multicolumn{2}{|c|}{$\left(\mathrm{cm}^{2} \mathrm{~m}^{-1}\right)$} & \\
\hline \multirow{2}{*}{$\begin{array}{l}\text { Positive } \\
\text { moment } \\
\text { Negative } \\
\text { moment }\end{array}$} & 14.98 & & 14.33 & 2.5 & 2.5 & \multirow{2}{*}{-0.6} \\
\hline & 32.57 & & 26.70 & 5.0 & 5.0 & \\
\hline \multicolumn{2}{|c|}{$\begin{array}{c}\text { Total weight / CA -50 } \\
(\mathrm{kg})\end{array}$} & \multicolumn{3}{|c|}{$\begin{array}{l}\text { Vol. total concrete / } \\
\text { C-30 }\left(\mathrm{m}^{3}\right)\end{array}$} & \multirow{2}{*}{\multicolumn{2}{|c|}{$\begin{array}{l}\text { verall shape area } \\
\qquad\left(\mathrm{m}^{2}\right)\end{array}$}} \\
\hline \multicolumn{3}{|c|}{3474.7} & \multicolumn{2}{|c|}{49.9} & & 10.9 \\
\hline
\end{tabular}

$\mathrm{h}$ - slab thickness

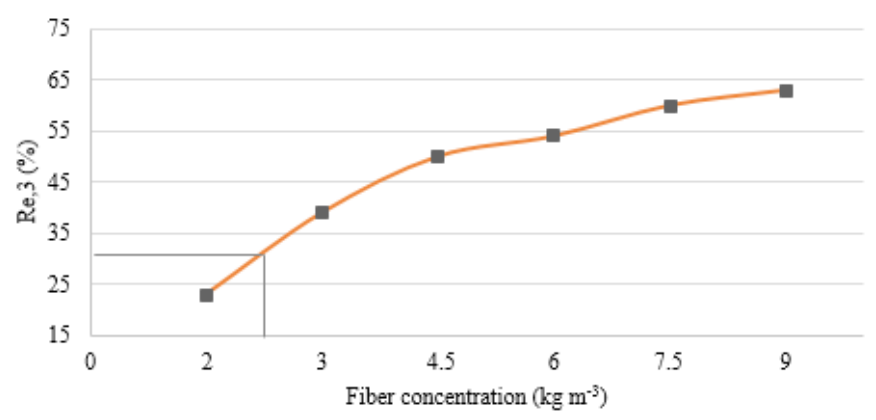

Figure 1. Coefficient of tenacity $\left(\mathrm{R}_{\mathrm{e}, 3}\right)$ as function of fiber concentration 
It was observed that the concrete solution reinforced with synthetic fibers promoted saving of $44.95 \%$ in comparison to the solution of the bottom slab of the silo in conventional reinforced concrete, costing in this case $\mathrm{R} \$ 35.765,50$ and $\mathrm{R} \$ 64.967,18$, respectively. That is, for the execution of $1 \mathrm{~m}^{2}$ of this element in concrete reinforced with fibers, the cost would be $\mathrm{R} \$ 134.20$, while for the execution of the same area in conventional reinforced concrete, the cost would be of $\mathrm{R} \$ 243.78$.

One of the factors that explain why the reinforcement with synthetic fibers for concrete presents itself as the most economical solution is the suppression of labor to make the frame in its execution process, as well as the cost of this material in equal reinforcement with respect to the bars of conventional steel.

\section{Conclusions}

1. The consistency index of concrete in fresh state decreases as the concentration of fibers increases. The addition of 3.0 $\mathrm{kg} \mathrm{m}^{-3}$ of fiber does not alter the consistency of the mixture.

2. The addition of the fibers significantly interfere in compressive strength, with higher values for $3.0 \mathrm{~kg} \mathrm{~m}^{-3}$ of fiber. Values above this concentration result in loss of resistance.

3. The solution for the application in the bottom slab of silos made of concrete reinforced with synthetic fibers promotes $44.95 \%$ saving compared to conventional reinforced concrete solution, showing as an attractive solution for such application.

\section{Literature Cited}

ABNT - Associação Brasileira de Normas Técnicas. NBR NM 67: Concreto - Determinação da consistência pelo abatimento do tronco de cone. Rio de Janeiro: ABNT, 1998. 8p.

ABNT - Associação Brasileira de Normas Técnicas. NBR 5739: Concreto - Ensaios de compressão de corpos de prova cilíndricos. Rio de Janeiro: ABNT, 2007. 9p.

ABNT - Associação Brasileira de Normas Técnicas. NBR 12142: Concreto - Determinação da resistência à tração na flexão de corpos de prova prismáticos. Rio de Janeiro: ABNT, 2010. 5p.

ABNT - Associação Brasileira de Normas Técnicas. NBR 6118: Projeto de estruturas de concreto - Procedimento. Rio de Janeiro: ABNT, 2014. 238p.

ACI - American Concrete Institute. ACI 360R-10: Guide to design of slabs-on-ground. Michigan: ACI, 2010. 72p.

Amaral Júnior, J. C. do; Silva, L. C. F.; Moravia, W. G. Análise experimental da adição de fibras poliméricas nas propriedades mecânicas do concreto. Revista Matéria, v.22, p.1-9, 2017. https:// doi.org/10.1590/s1517-707620170001.0112

Balevičius, R.; Sielamowicz, L.; Mróz, Z.; Kačianauskas, R. Investigation of wall stress and outflow rate in a flat-bottomed bin: A comparison of the DEM model results with the experimental measurements. Powder Technology, v.214, p.322-336, 2011. https://doi.org/10.1016/j.powtec.2011.08.042

Diniz, M. J.; Nascimento, J. W. B. do. Análise de pressões em silo vertical de alvenaria de tijolos. Revista Brasileira de Engenharia Agrícola e Ambiental, v.10, p.212-219, 2006. https://doi. org/10.1590/S1415-43662006000100031
Ehrenbring, H. Z.; Tutikian, B. F.; Quinino, U. C. de M. Análise comparativa da retração por secagem de concretos com fibras novas e recicladas de poliéster. Ambiente Construído, v.18, p.195209, 2018. https://doi.org/10.1590/s1678-86212018000300276

Fank, M. Z.; Nascimento, J. W. B. do; Cardoso, D. L.; Meira, A. S.; Willrich, F. L. Vertical pressures and compressive friction force in a large silo. Engenharia Agrícola, v.38, p.498-503, 2018. https:// doi.org/10.1590/1809-4430-eng.agric.v38n4p498-503/2018

Gallego, E.; González-Montellano, C.; Ramírez, A.; Ayuga, F. A simplified analytical procedure for assessing the worst patch load location on circular steel silos with corrugated walls. Engineering Structures, v.33, p.1940-1954, 2011. https://doi.org/10.1016/j. engstruct.2011.02.032

Ghahremannejad, M.; Mahdavi, M.; Saleh, A. E.; Abhaee, S.; Abolmaali, A. Experimental investigation and identification of single and multiple cracks in synthetic fiber concrete beams. Case Studies in Construction Materials, v.9, p.1-16, 2018. https://doi. org/10.1016/j.cscm.2018.e00182

Horabik, J.; Parafiniuk, P.; Molenda, M. Experiments and discrete element method simulations of distribution of static load of grain bedding at bottom of shallow model silo. Biosystems Engineering, v.149, p.60-71, 2016. https://doi.org/10.1016/j. biosystemseng.2016.06.012

JSCE - The Japan Society of Civil Engineers. JSCE-SF1: Method of making steel fiber reinforced concrete in the laboratory. Tokyo: JSCE, 1984. 3p.

Leone, M.; Centonze, G.; Colonna, D.; Micelli, F.; Aiello, M. A. Fiber-reinforced concrete with low concentration of recycled steel fiber: Shear behaviour. Construction and Building Materials, v.161, p.141-155, 2018. https://doi.org/10.1016/j. conbuildmat.2017.11.101

Lopes Neto, J. P.; Nascimento, J. W. B. do; Fank, M. Z. Forças verticais e de atrito em silos cilíndricos com fundo plano. Revista Brasileira de Engenharia Agrícola e Ambiental, v.18, p.652-657, 2014. https://doi.org/10.1590/S1415-43662014000600013

Monteiro, V. M. de A.; Lima, L. R.; Silva, F. de A. On the mechanical behavior of polypropylene, steel and hybrid fiber reinforced self-consolidating concrete. Construction and Building Materials, v.188, p.280-291, 2018. https://doi.org/10.1016/j. conbuildmat.2018.08.103

Mostafazadeh, M.; Abolmaali, A. Shear behavior of synthetic fiberreinforced concrete. Advances in Civil Engineering Materials, v.5, p.371-386, 2016. https://doi.org/10.1520/ACEM20160005

Nascimento, J. W. B. do; Lopes Neto, J. P.; Montross, M. D. Horizontal pressures in cylindrical metal silos and comparison with different international standards. Engenharia Agrícola, v.33, p.601-611, 2013. https://doi.org/10.1590/S0100-69162013000400002

Neves, J. B.; Lima, J. M. F.; Lima, P. R. L. Método das diferenças finitas energéticas para simulação do comportamento sob flexão do concreto reforçado com fibras de aço. Revista Sul-Americana de Engenharia Estrutural, v.10, p.31-55, 2013. https://doi. org/10.5335/rsee.v10i2.2667

Pieraccini, L.; Palermo, M.; Stefano, S.; Trombetti, T. On the fundamental periods of vibration of flat-bottom groundsupported circular silos containing gran-like material. Procedia Engineering, v.199, p.248-253, 2017. https://doi.org/10.1016/j. proeng.2017.09.015 
PINI. Tabelas de Composição de Preços para Orçamentos (TCPO). 15.ed. São Paulo: Pini, 2015. 630p.

Pyo, S.; Wille, K.; El-Tawil, S.; Naaman, A. Strain rate dependent properties of ultra high performance fiber reinforced concrete (UHP-FRC) under tension. Cement and Concrete Composites, v.56, p.15-24, 2015. https://doi.org/10.1016/j.cemconcomp.2014.10.002

Rotter, J. M.; Sadowski, A. J. Cylindrical shell bending theory for orthotropic shells under general axisymmetric pressure distributions. Engineering Structures, v.42, p.258-265, 2012. https://doi.org/10.1016/j.engstruct.2012.04.024

Salvador, R. P.; Figueiredo, A. D. de. Análise comparativa de comportamento mecânico de concreto reforçado com macrofibra polimérica e com fibra de aço. Revista Matéria, v.18, p.1273-1285, 2013. https://doi.org/10.1590/S1517-70762013000200003

SINAPI - Sistema Nacional de Pesquisa de Custos e Índices da Construção Civil. João Pessoa: SINAPI, 2017. 541p.
Wang, P.; Zhu, L.; Zhu, X. Flow pattern and normal pressure distribution in flat bottom silo discharged using wall outlet. Powder Technology, v.295, p.104-114, 2016. https://doi. org/10.1016/j.powtec.2016.03.036

Wen, P.; Wang, G.; Hao, D.; Zheng, N.; Li, L.; Shi, Q. Bottom stresses of static packing of granular chains. Physica A: Statistical Mechanics and its Applications, v.419, p.457-463, 2015. https:// doi.org/10.1016/j.physa.2014.10.062

Yaghoobi, A.; Chorzepa, M. G. Fracture analysis of fiber reinforced concrete structures in the micropolar peridynamic analysis framework. Engineering Fracture Mechanics, v.169, p.238-250, 2017. https://doi.org/10.1016/j.engfracmech.2016.11.004

Yoo, D.; Yoon, Y.; Banthia, N. Flexural response of steel-fiberreinforced concrete beams: Effects of strength, fiber concentration, and strain-rate. Cement and Concrete Composites, v.64, p.84-92, 2015. https://doi.org/10.1016/j.cemconcomp.2015.10.001 